\title{
MEDIA LITERASI SEBAGAI UPAYA PENGUATAN KESADARAN PENGARUH NEGATIF MEDIA DIGITAL TERHADAP ANAK - ANAK
}

\author{
Latifa Zahra dan Bagus Ajy Waskyto Sugiyanto
}

Prodi Ilmu Komunikasi, FISIPOL, Universitas Widya Mataram Yogyakarta

ifayuki@gmail.com, bagusajy89@gmail.com

\begin{abstract}
The Sophistication of digital media provides how easy to access about information in almost all aspects of society. The leap of technological sophistication is too rapid makes the negative impact of digital media increasingly disguised. This community service aims to improve the understanding of housewives regarding the negative impact of digital media on children. Using the adult approach method, this service activity actually looks for cases from within the community itself, and guides the community to find solutions to problems from themselves. At the end of the activity, it was known that housewives in the Demen, Pakem, Sleman area had knowledge of the negative impact of digital media on children, but awareness of its long-term impact still became homeworks not only for the mothers themselves, but also the other stakeholders.
\end{abstract}

Keywords: Literacy, Digital Media, PKK, Children, Community Service

\begin{abstract}
Abstraksi
Kecanggihan media digital memberikan kemudahan akses informasi hampir kepada seluruh aspek masyarakat. Loncatan kecanggihan tekonologi yang terlalu pesat justru membuat dampak negatif media digital semakin tersamarakan. Pengabdian kepada masayarakat ini bertujuan untuk meningkatkan pemahaman ibu rumah tangga terkait dampak negatif media digital terhadap anak anak. Dengan menggunakan metode pendekatan orang dewasa, kegiatan pengabdian ini justru mencari kasus dari dalam komunitas sendiri, serta memandu komunitas untuk mencari pemecahan masalah dari diri mereka sendiri. Di akhir kegiatan, diketahui bahwa ibu rumah tangga di wilayah Demen, Pakem, Sleman telah memiliki pengetahuan mengenai dampak negative media digital terhadap anak - anak, namun kesadaran menganai dampak jangka panjangnya masih menjadi PR tidak hanya untuk ibu - ibu sendiri, namun pemangku kepentingan lainnya.
\end{abstract}

Kata Kunci : Literasi, Media Digital, PKK, Anak-anak, Pengabdian Masyarakat 


\section{PENDAHULUAN}

Melihat Media digital berarti melihat pemberian aksesbilitas tanpa kendala ruang dan waktu sehingga menyebabkan perubahan pola komunikasi pada banyak aspek. Ruang akselerasi yang tinggi adalah kelebihan media digital dibandingkan dengan platform media media sebelumnya. Mc Luhan dalam Mauludi (2018) menyatakan bahwa media merupakan kepanjangan dari manusia. Media adalah alat bantu manusia. Namun kemudian, sekali lagi Mc Luhan mengatakan bahwa "Kita yang membentuk alat - alat dan setelah itu alat alat yang membentuk kita”. Jika menilik perkembangannya saat ini, dengan menilik bagaimana perkembangan media digital hal ini menjadi benar.

Media digital diciptakan untuk memberikan kemudahan bagi manusia, namun pada perjalannya manusia terbalik menjadi bergantung kepada media. Pergeseran ini merupakan hal yang wajar, mengingat sebelum ditemukannya internet dan media digital, masyarakat merupakan warga yang pasif. Pembentukan ruang produksi pesan yang canggih memaksa masyarakat menjadi aktif tanpa menyadari dampak yang ditimbulkan. Tuntutan untuk mengikuti zaman menimbulkan permasalahan komunikasi. Penyebaran konten hoax, cyberbullying, penyebaran konten kebencian, demam gawai dan lain-lain.

Penggunaan media digital yang telah tersambung dengan internet perlu pengawasan yang sangat protektif. Seperti yang diutarakan Dieter Baacke, definitif tidaknya potensi publik dalam melakukan negosiasi dan perlawanan atau sebaliknya mengamini konstruksi disfungsional media pada dasarnya aakan ditentukan tinggi rendahnya media consciounsess (kesadaran bermedia) sebagai bagian preferensi kulturan yang mereka miliki (Danarka Sasangka 2012:15). Baacke membagi kesadaran media menjadi dua ruang besar yang saling bertautan. Masing-masing adalah kesadaran di tingkat etis-analitis dan kesadaran tingkat teknis-prosedural. Yang pertama membicarakan kemampuan khalayak dalam mengevaluasi secara ktitis suatu kontruksi wacana yang diberikan media dengan berdasarkan pada nilai-nilai normatif yang berlaku serta pertimbangan social cost benefit atas implikasi sosial yang berpotensi dari kehadiran wacana tersebut. Sedangkan kesadaran yang kedua menyangkut pengetahuan publik atas hak dan tanggung jawab mereka maupun media dalam menciptakan atmosfir kehidupan bermedia yang sehat. Dua kesadaran ini adalah basisbasis yang relevan unntuk diaktivasi melalui gerakan literasi media kepada masyarakat.

Pengetahuan seperti hal tersebut perlu ditanamkan semenjak dini. Anak - anak zaman sekarang rentan atas pengaruh negative dari bermedia digital. Sejak usia dini, mereka telah dibiasakan untuk bersentuhan dengan gadget.

Berlokasi di Dusun Demen yang terletak di Jalan Kaliurang KM 17, pengabdian pada masyarakat ini mengusung masalah kerentanan anak - anak terhadap produk - produk negative dari media digital. Dimulai dari penyadaran ibu - ibu rumah tangga sebagai pintu masuk edukasi, diharapkan mereka dapat menjadi agen perubahan bagi keluaraga khususnya anak anak. 
Ibu Rumah Tangga di Dusun Demen memiliki kelompok PKK yang secara rutin berkumpul setiap satu bulan sekali. Kegiatan ini diikuti seluruh ibu rumah tangga, yang beranggotakan kurang lebih 60 orang. Tidak ada syarat khusus untuk menjadi anggota dari PKK, asal telah berkeluarga, otomatis dapat menjadi anggota perkumpulan. Terkait pemilihan objek fasilitasi yaitu ibu rumah tangga berlokasi di Dusun Demen, Pakembinangun, Pakem, Sleman, Yogyakarta tentu saja tidak bermaksud mengecilkan peran ibu rumah tangga hanya dalam ranah domestik saja, tetapi melihat dari kacamata antropologi keluarga Jawa yang memiliki tipologi yang khas dan tanggung jawab antar anggota keluarga. Konsep yang digunakan dalam keluarga Jawa adalah keluarga inti konjugal disebut Engles sebagai keluarga borguise yang mencerrminkan relasi head complement yang bertumpu pada karir dan penghasilan utama suami dan peran domestik istri sebagai ibu rumah tangga (Rosalind, 1987:133).

Melihat permasalahan tersebut, pengabdian pada masyarakat ini bertujuan untuk meningkatkan pemahaman ibu rumah tangga terkait dampak negatif media digital terhadap anak - anak.

\section{METODE}

Dalam kasus ini, metode yang digunakan adalah pendekatan kualitatif dengan langkah pendekatan orang dewasa. Metode pendekatan orang dewasa adalah upaya penggalian pengalaman pribadi sehingga ditemukan permasalahan permasalahan dasar untuk akhirnya terpecahkan dengan dari kasus mereka sendiri.
Untuk menggali permasalahan secara tersendiri, para peserta pengabdian awalnya dibagi menjadi 2 kelompok.

Sebelum itu pola rekrutmen peserta dalam pengabdian masyarakat ini adalah dengan mengumpulkan ibu-ibu rumah tangga di daerah tempat pengabdian. Orang tua yang dimaksudkan terutama yang masih memiliki anak dalam usia anak (mulai dalam kandungan s/d 60 tahun). Jumlah orang tua tersebut sekitar 40 orang tua yang dipilih dengan cara meminta pertimbangan dari para pemangku wilayah dengan berdasar pula dari analisis kondisi-kondisi keluarga yang ada.

\section{HASIL DAN PEMBAHASAN}

Dalam kurun waktu 1,5 jam, tim pengabdian melakukan penetrasi materi kepada ibu - ibu rumah tangga yang terkumpul dalam PKK untuk terlebih dahulu mengetahui pengetahuan bermedia dari mereka. Setelah itu baru akan digali lebih jauh mengenai pemehaman mereka terhadap dampak - dampak yang ditimbulkan, khususnya terhadap anak - anak mereka.

Pelaksanaan kegiatan dilakukan pada Bulan Desember 2018 dihadiri kurang lebih 25 orang perwakilan ibu - ibu rumah tangga PKK Dusun Demen. Kedua puluh lima ibu ibu rumah tangga tersebut terbagi menjadi beberapa rentan umur yang berbeda.

Sebelum melaksanakan diskusi, disepakati terlebih dahulu kontrak diskusi. Hal ini terkait dengan kelancaran proses diskusi, dimana seluruh peserta diminta untuk berani mengungkapkan pendapat dan menghormati peserta lain saat mereka berendapat. 
Setelah itu, dijelaskan mengenai alur diskusi. Kegiatan ini bertujuan memberi fokus kepada diskusi agar tidak keluar dari jalur.

\section{Gambar 1}

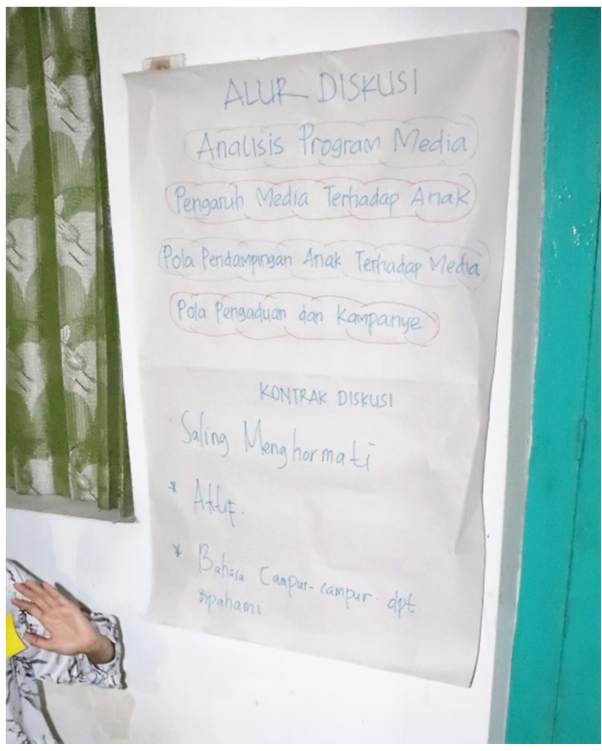

\section{Penjelasan Mengenai Alur Diskusi Materi dan Penetapan Kontrak Diskusi}

Ada beberapa indicator yang digunakan untuk melihat terjadinya peningkatan kesadaran ibu - ibu rumah tangga terhadap dampak negatif penggunaan media terhadap anak - anak. Indikator tersebut sebagai berikut :

a. Terbangunnya kesadaran ibu - ibu PKK mengenai penggunaan media digital.

b. Terbangunnya pemahaman ibu - ibu PKK mengenai dampak pemberian media digital kepada anak - anak

c. Terbangunnya komitmen ibu - ibu PKK untuk menjadi agen literasi media.

Dari hasil diskusi dan pelatihan literasi media digital untuk membangun kesadaran ibu - ibu PKK mengenai dampak negatif kepada anak - anak, ditemukan bahwa sebenarnya ibu - ibu mengetahui dampak dampak tersebut.

Mereka paham bahwa pemberian dan penggunaan media digital yang terlalu lama dapat menyebabkan demam gawai kepada anak - anak. Beberapa ibu - ibu memberikan argumen bahwa di dalam keluarga mereka diberikan aturan yang ketat terhadap penggunaan media digital. Hal ini ditemukan di keluarga - keluarga yang memiliki anak anak balita. Pada saat anak - anak balita, penggunaan aturan yang ketat mungkin dapat dilakukan, namun seiring berjalannya waktu, perlu disadari bahwa metode ini bisa saja menjadi metode yang sudah kurang efektif.

\section{Gambar 2}

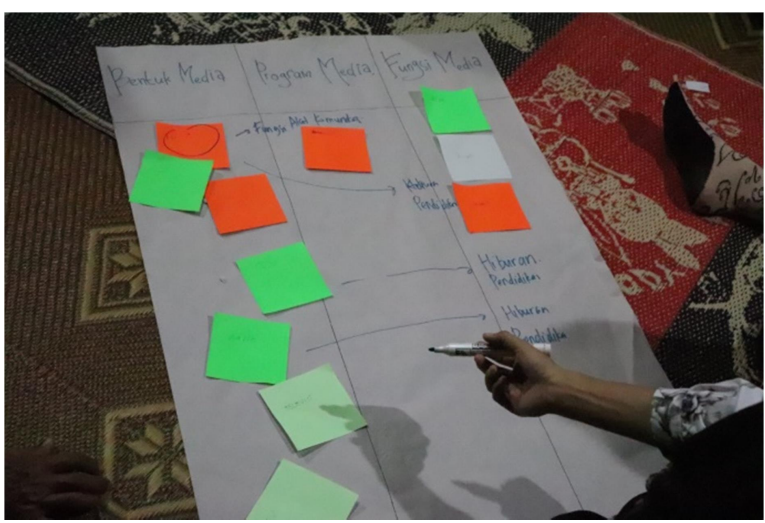

\section{Media Dalam Penggunaan Metode Orang} Dewasa di Kegiatan Literasi Media Digital

Seorang peserta yang merupakan guru di sebuah SMP di wilayah tersebut menceritakan bahwa, sidak yang dilakukan kepada murid - muridnya menemukan bahwa beberapa murid yang memiliki media digital menyimpan konten - konten porno. Lebih jauh lagi, diceritakan bahwa orang tua dari anak tersebut justru tidak mengetahui kegiatan 
anaknya, hal ini dikarenakan karakter anaknya yang justru pendiam.

Perihal dampak negatif media digital nyatanya telah disadari oleh Ibu - Ibu tersebut, namun di lain sisi mereka seperti tidak memiliki kemampuan untuk melarang. Di satu sisi, ibu - ibu merasa terbantu oleh media digital dalam pengasuhan anak disaat mereka butuh waktu untuk bekerja.

Pemberian media - media alternative seperti buku atau membangkitkan kembali permainan - permainan tradisional dapat menjadi solusi dalam pengurangan penggunaan media digital kepada anak - anak.

\section{PENUTUP}

Kesadaran ibu - ibu terhadap dampak negatif penggunaaan media digital sudah mulai terbangun. Kegiatan literasi media digital kepada ibu - ibu PKK sebagai upaya penguatan kesadaran terhadap dampak negatif kepada anak - anak berjalan dengan lancar. Kegiatan ini dirasa banyak memberikan manfaat kepada ibu - ibu, dibuktikan dengan respon mereka untuk mengadakan pelatihan lanjutan yang scope-nya diharapkan dapat diperlebar.

Kegiatan literasi media digital dengan metode pendekatan orang dewasa belum pernah dilaksanakan sebelumnya. Kegiatan ini akan lebih bermafaat jika mampu bekerjasama dengan pihak - pihak lainnya, seperti pemerintah atau lembaga lain, sehingga tercipta sebuah lahan media alternative yang nyata untuk menunjang reduksi penggunaan media digital dan dampaknya terhadap anak anak.

\section{DAFTAR PUSTAKA}

A. Sydie, Rosalind. 1987. Natural Women and Cultured Men: A Feminist Perpective on Sociological Theory. England: Open University Press.

Barker, Chris. 1999. Television, Globalization and Cultural Identities. Buckingham: Open University Press.

McLuhan, Marshall. 1994. Understanding Media The Extension of Man. Massachusetts Institute of Technology Press.

Mauludi, Sahrul. 2018. Socrates Café. Jakarta : PT Elex Media Komputindo. 